\title{
Pathological changes induced by repeated percutaneous transluminal coronary angioplasty
}

\author{
MAKIKO UEDA, * ANTON E BECKER, $\dagger$ TERUO FUJIMOTO* \\ From the Departments of Pathology, †University of Amsterdam, Academic Medical Center, Amsterdam, The

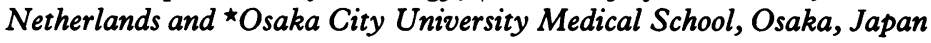

SUMMARY The histopathological appearances of seven coronary arteries obtained from four patients after repeated percutaneous transluminal coronary angioplasty were analysed. A complex picture was found; typically there were ruptured atherosclerotic plaques, plaque dissection, and a fibrous tissue response. The histopathological appearance of older and more recent fibrous lesions was different. Older lesions contained more collagen and elastin fibres, whereas recent ones had more loosely arranged connective tissue containing abundant glycosaminoglycan and readily identifiable cells. The fibrous tissues tended to be damaged at the sites of previous injury and where the vessel wall was thinnest. In five of the seven arteries there was evidence of a repeated fibrous response to injury with partial or total rupture of the original media. In one instance a repair response within a pre-existing atherosclerotic plaque had caused restenosis.

The results indicate that restenosis after repeated percutaneous transluminal coronary angioplasty, like restenosis after a first procedure, is mainly the result of fibrocellular tissue response to injury of the wall tissues. Because older (that is more mature) repair tissue contains fewer cells and more connective elements than younger repair tissue (that is the loosely arranged connective tissue found soon after angioplasty), when it is disrupted by a further angioplasty procedure it is less capable of producing tissue that will obstruct the lumen. This may explain why in the majority of patients with restenosis repeated percutaneous transluminal coronary angioplasty is successful. The present study also showed that occasionally plaque haemorrhages may become organised and incorporated into the pre-existing atherosclerotic lesion.

Restenosis is a major complication of percutaneous transluminal coronary angioplasty. Follow up angiography showed a high frequency $(33.6 \%)$ of restenosis in patients on a register of percutaneous transluminal coronary angioplasty procedures. ${ }^{1}$ Treatment of coronary restenosis by repeat percutaneous coronary angioplasty has a high immediate success rate and a low complication rate, but follow up angiographic examinations showed restenosis in $34 \%$ of these patients. ${ }^{2}$

Pathological changes underlying restenosis after a first coronary angioplasty procedure have been recognised. ${ }^{3-14}$ Although several questions still remain

Requests for reprints to Professor Anton E Becker, Department of Pathology, Academic Medical Center, Meibergdreef 9, 1105 AZ Amsterdam-Zuidoost, The Netherlands.

Accepted for publication 9 July 1987 the consensus is that in most instances restenosis is caused by fibrocellular proliferation which is probably prompted by injury to the vascular smooth muscle cells. There are two reports of restenosis caused by atherosclerotic plaques in the absence of morphological lesions that were attributable to the angioplasty procedure. ${ }^{810}$

To the best of our knowledge the pathological changes found after repeated percutaneous transluminal coronary angioplasy have not been described before.

\section{Patients and methods}

The heart specimens were obtained from four patients. Table 1 gives the relevant clinical data. Repeated percutaneous transluminal coronary angioplasty of seven arteries had been performed because of recurrent angina pectoris and associated 
Table 1 Clinical data associated with pathological findings

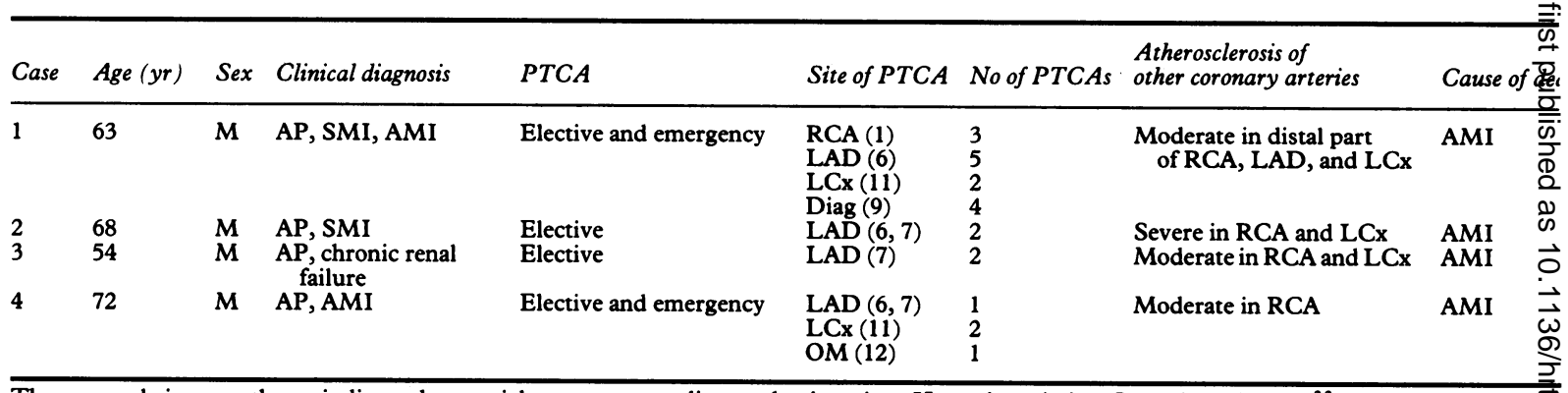

The numerals in parentheses indicate the arterial segment according to the American Heart Association Committee Report. ${ }^{22}$ Moderate atheroscle lesions, $50-75 \%$ stenosis; severe atherosclerotic lesions $>75 \%$ stenosis. AMI, acute myocardial infarction; AP, angina pectoris; diag, diagonal; LAB, anterior descending coronary artery; LCA, main left coronary artery; LCx, left circumflex artery; OM, obtuse marginal artery; PTCA, percutain transluminal coronary angioplasty; RCA, right coronary artery; SMI, scarred myocardial infarct.

restenosis. Patients had had from one to five percutaneous transluminal coronary angioplasty procedures. Table 2 shows the interval between the last percutaneous transluminal coronary angioplasty procedure and death.

\section{Pathological examination}

In each case the complete heart was available for study. After fixation in buffered formalin, the coro- nary arteries were removed from the epicardial sur- 0 face and decalcified before sectioning. The arteries in which the percutaneous transluminal coronary angioplasty had been performed were sectioned serially every $1-2 \mathrm{~mm}$ for $8 \mathrm{~cm}$ from the origin of the vessels. The other coronary arteries were sectioned serially every $3 \mathrm{~mm}$ for $6 \mathrm{~cm}$ from the origin. All blocks were routinely processed and $5 \mu \mathrm{m}$ thick sections were prepared. The sections were stained with . haematoxylin and eosin, an elastic stain counter-

Table 2 Pathological findings in coronary arteries after repeated percutaneous transluminal coronary angioplasty

\begin{tabular}{|c|c|c|c|c|c|c|}
\hline \multirow{3}{*}{ Case } & \multirow{2}{*}{\multicolumn{2}{|c|}{ Artery ${ }^{\star}$}} & \multirow{3}{*}{ No of PTCAs } & \multirow{2}{*}{\multicolumn{2}{|c|}{$\begin{array}{l}\text { Interval between } \\
\text { PTC } A \text { and death }\end{array}$}} & \multirow{3}{*}{$\begin{array}{l}\text { Wall laceration } \\
\text { Intima }\end{array}$} \\
\hline & & & & & & \\
\hline & RCA & (1) & & $\begin{array}{l}2 \text { hours } \\
1 \text { month } \\
5 \text { months, }\end{array}$ & $\begin{array}{r}23 \text { days } \\
7 \text { days }\end{array}$ & \\
\hline & Diag & (9) & 4 & $\begin{array}{l}2 \text { hours } \\
2 \text { months, } \\
5 \text { months, } \\
7 \text { months }\end{array}$ & $\begin{array}{l}15 \text { days } \\
22 \text { days }\end{array}$ & $\begin{array}{l}\text { Plaque rupture, recent haemorrhage; receü } \\
\text { earlier laceration of fibrocellular tissue; gaf } 1 \\
\text { with young proliferative tissue }\end{array}$ \\
\hline & LAD & (6) & 5 & $\begin{array}{l}2 \text { hours } \\
2 \text { months, } \\
3 \text { months. } \\
5 \text { months, } \\
7 \text { months, }\end{array}$ & $\begin{array}{r}15 \text { days } \\
6 \text { days } \\
22 \text { days } \\
10 \text { days }\end{array}$ & $\begin{array}{l}\text { Plaque rupture, recent haemorrhage; old } \dot{\text { la }} \\
\text { rupture, organised haemorrhage; dissection } \\
\text { laceration of fibrocellular tissue (dating fron } \\
\text { earlier procedure) extending into main LCA }\end{array}$ \\
\hline & LCx & (11) & 2 & $\begin{array}{l}2 \text { months, } \\
7 \text { months, }\end{array}$ & $\begin{array}{l}15 \text { days } \\
10 \text { days }\end{array}$ & $\begin{array}{l}\text { Plaque rupture, organised haemorrhage; } \\
\text { tion of fibrocellular tissue (dating from an } \\
\text { procedure); dissection and gap filled with } \\
\text { proliferative fibrous tissue }\end{array}$ \\
\hline 2 & LAD & $(6,7)$ & 2 & $\begin{array}{l}3 \text { months, } \\
4 \text { months, }\end{array}$ & $\begin{array}{l}10 \text { days } \\
7 \text { days }\end{array}$ & $\begin{array}{l}\text { Plaque rupture, dissection; fibrous respons } \\
\text { organised haemorrhage (continued intoc r } \\
\text { LCA) }\end{array}$ \\
\hline 3 & LAD & (7) & 2 & $\begin{array}{l}2 \text { months, } \\
6 \text { months, }\end{array}$ & $\begin{array}{l}18 \text { days } \\
17 \text { days }\end{array}$ & $\begin{array}{l}\text { Dissection and rupture plaque-free wald } \\
\text { media; old plaque dissection and } \\
\text { organised haemorrhage; fibrocellular tissue } \\
\text { from an earlier procedure) in old dissection; yc } \\
\text { fibrous tissue in more recent laceration }\end{array}$ \\
\hline 4 & LCx & (11) & 2 & $\begin{array}{l}1 \text { day } \\
10 \text { months, }\end{array}$ & 3 days & $\begin{array}{l}\text { Plaque dissection and rupture into } \\
\text { organised haemorrhage, dissection partially fil } \\
\text { with thrombus and partially with fibrous tissu }\end{array}$ \\
\hline
\end{tabular}

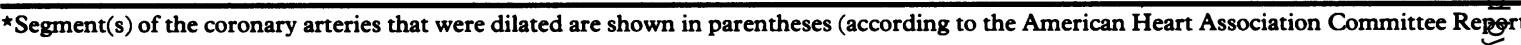


stained with Van Gieson's stain, and a phosphotungstic acid haematoxylin stain. The blocks taken from the sites of the percutaneous transluminal coronary angioplasty were serially sectioned, whereas step sections were taken from the remaining blocks. When necessary additional sections were also mounted.

The myocardium was studied by cutting the heart in parallel slices, perpendicular to the left ventricular long axis. Full thickness slices were then taken for histological examination, at different levels, to include both the left and right ventricles.

\section{Results}

Table 2 shows the most important pathological features found in the coronary arteries.

Dissection and rupture of pre-existing atherosclerotic plaques was detected in all seven arteries. There was plaque rupture with recent haemorrhage and mural thrombosis in three arteries (case 1: right coronary artery, diagonal branch, left anterior descending coronary artery), which had been dilated two hours before death.

Pre-existing eccentric atherosclerotic plaques were damaged where the plaque was attached to the underlying media and pre-existing concentric lesions were damaged at their thinnest part (fig 1). Rupture sites and dissection clefts were filled with fibrous tissue, which indicated the stage of healing. Laceration of repair tissue was clearly indentifiable. Older repair tissue contained more collagen and elastin fibres than more recently formed tissue which had a looser texture and contained abundant glycosaminoglycans and readily identifiable cells. Disruption of fibrous tissue tended to occur at the site of earlier injury, generally where the vessel wall was thinnest. In five of seven arteries evidence of a repeated fibrous response to injury was accompanied by partial or total rupture of the original media (fig 2). In one instance (case 1: left anterior descending coronary artery) cholesterol filled the dissection cleft between a pre-existing atherosclerotic plaque and the media (fig 3 ).

In three arteries attenuation and separation of smooth muscle cells had disrupted the media at the site that initially was considered to be plaque free (fig 4).

In one instance (case 4) there was massive dissection of the coronary arteries. The first attempt to dilate the left circumflex artery (10 months and 13 days before death) probably caused plaque dis-

\begin{tabular}{|c|c|c|c|c|c|}
\hline \multirow[b]{2}{*}{ Media } & \multirow{2}{*}{$\begin{array}{l}\text { Medial smooth } \\
\text { muscle cells } \\
\text { attenuation/disruption }\end{array}$} & \multirow[b]{2}{*}{ Thrombosis } & \multirow[b]{2}{*}{ Restenosis } & \multicolumn{2}{|c|}{ Tissue response underlying restenosis } \\
\hline & & & & $\begin{array}{l}\text { Fibrocellular } \\
\text { proliferation }\end{array}$ & Atherosclerosis \\
\hline & Attenuation & Recent thrombus & + & + & - \\
\hline Partial and total rupture & (Rupture) & Recent thrombus & + & - & + \\
\hline \multirow[t]{2}{*}{ Partial and total rupture } & Attenuation/disruption & Recent thrombus & + & + & - \\
\hline & (Rupture) & - & + & + & + \\
\hline Laceration of plaque-free wall & $\begin{array}{l}\text { Attenuation, disruption } \\
\text { of plaque-free wall }\end{array}$ & - & + & + & - \\
\hline Partial and total rupture & (Rupture) & - & + & + & - \\
\hline $\begin{array}{l}\text { Partial and total rupture; } \\
\text { dissection }\end{array}$ & (Rupture) & - & + & + & - \\
\hline
\end{tabular}




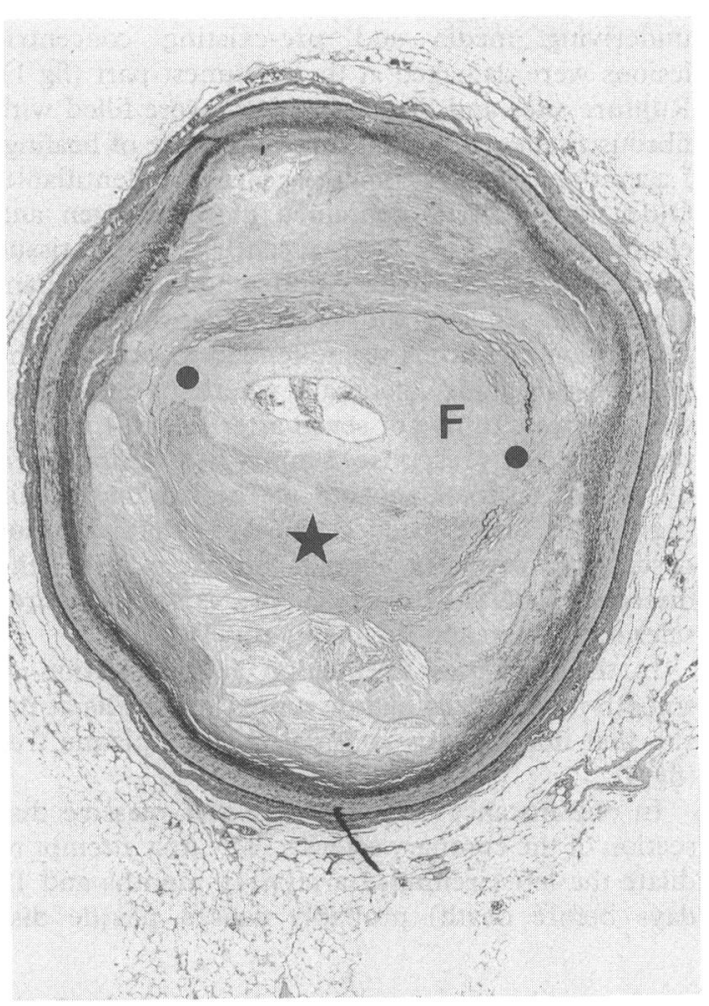

Fig 1 Photomicrograph showing concentric atherosclerotic obstruction of a coronary artery with tears where the thickness of the plaque and of the fibrocellular tissue layer was thinnest (black dots) after previous percutaneous transluminal coronary angioplasty (asterisk). A new layer of fibrocellular tissue $(F)$ has led to restenosis. Elastic tissue stains (original magnification, $\times 17 \cdot 5$ ).

section and rupture and limited dissection of the media. Fibrous tissue covered part of the false lumen. A subsequent attempt to dilate the left circumflex artery (a day before death) caused further dissection. During the second attempt at the same session the catheter was guided into the false lumen and further on into the obtuse marginal branch. Inflation of the balloon led to a dissection extending into the intramyocardial branches (fig 5). Instant cardiac shock developed and the patient died.

In all seven arteries there was narrowing (including pre-existing obstructive lesions not previously treated by balloon dilatation) of $\geqslant 50 \%$ of the lumen; thus all met the clinical criteria for restenosis. ${ }^{15}$ In six of the seven instances restenosis was caused by proliferation of fibrocellular tissue, after laceration of the vessel wall. In one instance (case 1: right coronary artery) there was restenosis caused by a repair process within a pre-existing ath- erosclerotic plaque (fig 6 ). The artery showed several surface irregularities that were covered by recent thrombosis; these were considered to be an effect of the most recent attempt at dilatation (two hours before death). Within pre-existing atherosclerotic plaques there were highly disorganised and cellular areas caused by proliferation of fibroblasts intermingled with many lipid laden macrophages and the occasional lymphocyte and dispersed iron deposits. In one artery (case 1: left anterior descending coronary artery) we found both a repair process within an atheroma and a fibrocellular tissue proliferation.

The myocardium of each of the four patients showed features of healed and acute myocardial infarction. In each of these instances death was considered to be related either directly to the last procedure or to pre-existing generalised obstructive coronary atherosclerosis (see table 1).

\section{Discussion}

We studied four hearts obtained from patients who died after repeated percutaneous transluminal coronary angioplasties for coronary artery restenosis in whom the initial procedure had been successful.

Histological examination of the seven arteries showed a complex structure, dominated by arterial wall laceration involving both pre-existing atherosclerotic plaques and fibrous repair tissue that was considered to have been produced in response to the initial injury. Indeed, in all instances the changes found at microscopy were in accord with the clinical history of repeated percutaneous transluminal coronary angioplasties. There was plaque rupture with dissection and damage to the underlying media in each instance. Laceration usually occurred at the end of the plaque in eccentric lesions and at the thinnest part of the arterial wall in concentric atherosclerotic lesions. There was fibrous tissue at the injury site characterised by well formed collagen and elastin fibres. Subsequent laceration of the arterial wall had caused further injury to the repair tissues and these newer sites were covered by a fibrocellular tissue rich in glycosaminoglycans that contained fewer collagen and elastin fibres. The history of each percutaneous transluminal coronary angioplasty procedure could be followed almost step by step.

In one artery cholesterol deposits were embedded within fibrous tissue at a site of initial plaque dissection with laceration of the media. This finding unequivocally demonstrates that atheromatous plaque rupture had occurred and that cholesterol embolisation is a potential complication of the procedure. Peripheral cholesterol embolisation in man 


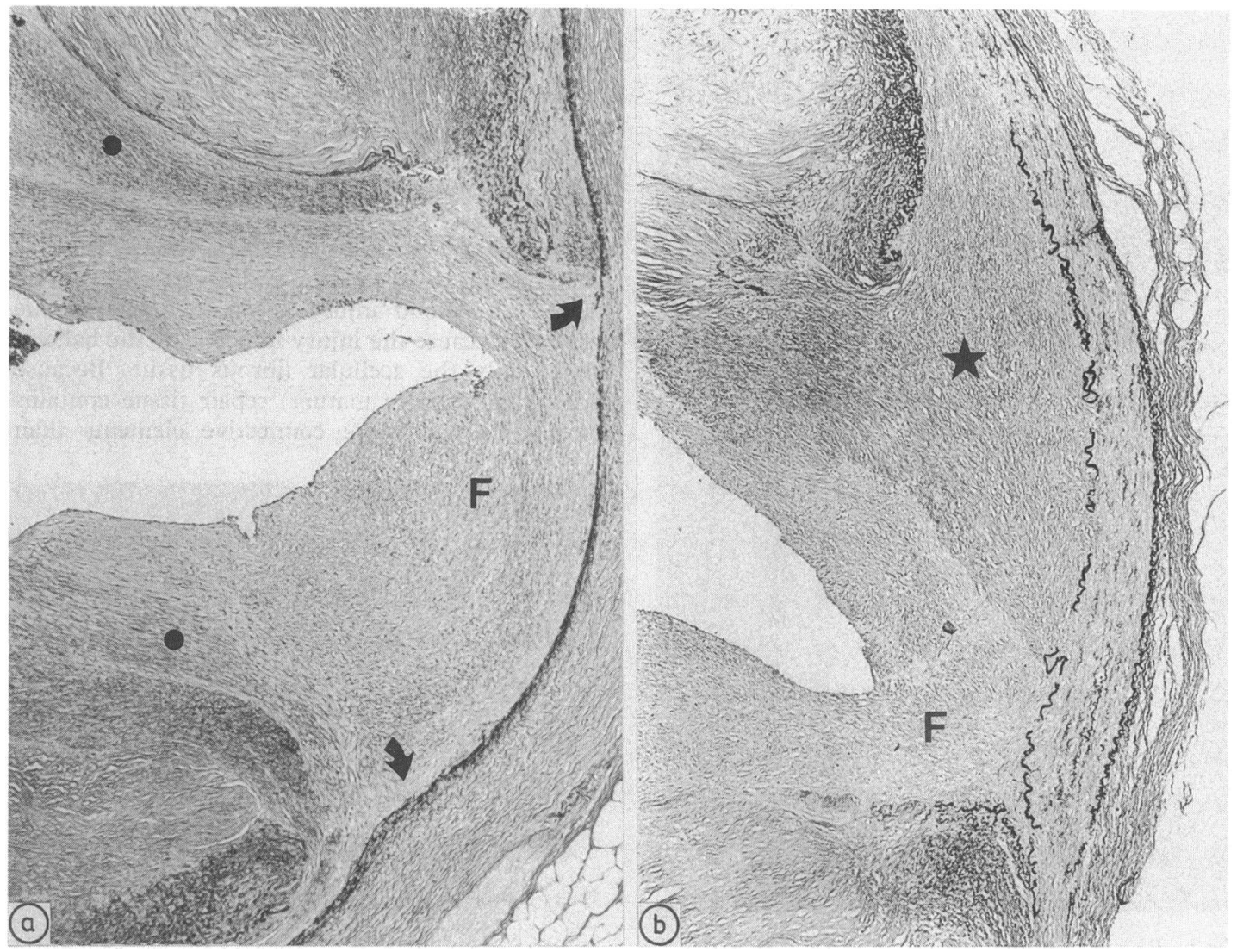

Fig 2 Photomicrograph showing different stages of fibrocellular tissue response in coronary arteries after repeated percutaneous transluminal coronary angioplasties. (a) Site from which pre-existing media has disappeared (arrows). This is filled with relatively young fibrocellular tissue $(F)$. This tissue covers a layer of fibrocellular tissue containing more elastin and collagen fibres, indicating a response to an earlier procedure (black dots). (b) An area of intimal disruption with superficial abrasion of the media. The gap is filled partly by fibrocellular tissue produced in response to an earlier procedure (asterisk) and partly by more loosely textured connective tissue, indicating a more recent origin $(F)$. Elastic tissue stains $a$ and $b$ (original magnification, $\times 55$ ).

has been reported, ${ }^{1416}$ but seems to be rare. A search for such emboli is tedious, however, and small emboli may be easily overlooked, as shown by experimental animal studies. ${ }^{1718}$

Despite the histological complexity of the lesions, we identified attentuation of smooth muscle cells with separation and disruption of the media in three arteries. The remaining specimens showed partial medial rupture. The interpretation of changes in the smooth muscle cells of the media of coronary arteries is not easy. Advanced arterial atherosclerosis usually produces thinning of the media with attentuation of smooth muscle cells. But we also found changes that were highly suggestive of over- stretching in segments of media without substantial intimal changes and when there was only a slightly elevated atheromatous lesion. This impression was supported by the observation of fragmented and often curly elastin fibres within the segments, which was commonly accompanied by an increase in fibrous tissue. These changes are distinct from the obvious thinning that occurs in association with atherosclerosis that was described by Isner and Fortin. ${ }^{19}$

It is tempting to view the observed changes in the media as being caused by overstretching of the wall by the radial pressure of the balloon. Attentuation and disruption of smooth muscle cells have also been 


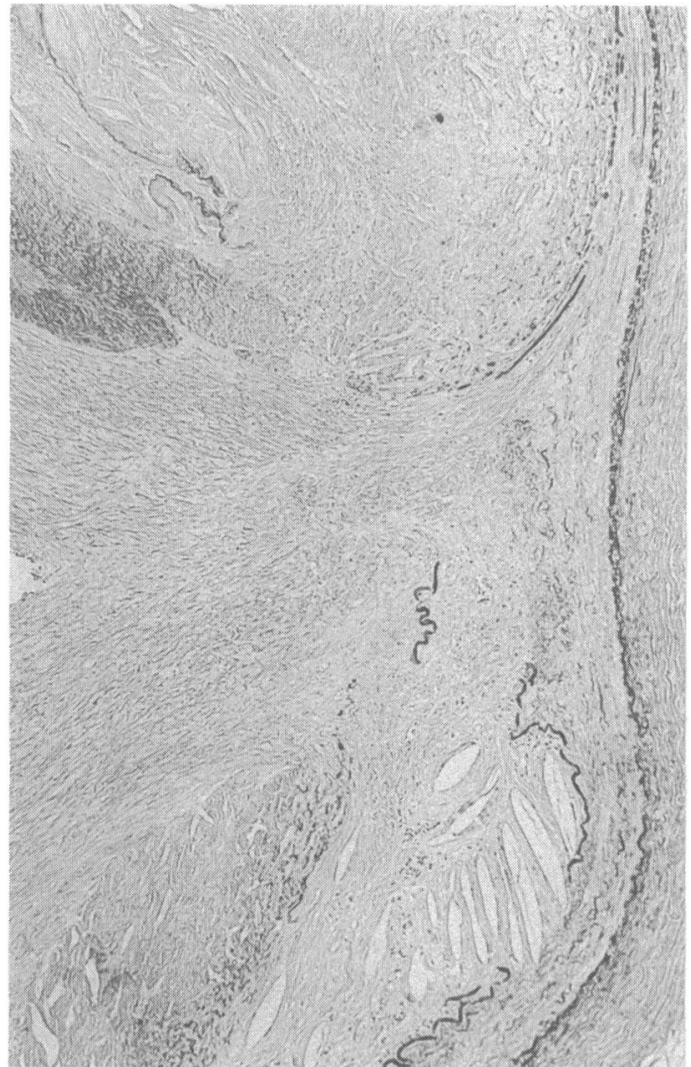

Fig 3 Photomicrograph showing cholesterol clefts within a dissection, which were encapsulated by fibrocellular tissue in response to injury. Elastic tissue stain (original magnification, $\times$ 55).

reported by Düber et al. ${ }^{13}$ They described necrosis of smooth muscle cells as a feature that occurs after vessel wall dilatation.

Dissection is another hazard of repeated percutaneous transluminal coronary angioplasty. This occurred in patient 4. The initial procedure had resulted in a dissection, which became partially filled with thrombus and partially coated by fibrous tissue. The repeat percutaneous transluminal coronary angioplasty procedure produced further dissection and the catheter was guided through the false channel from the left circumflex artery into the obtuse marginal branch. Inflation of the balloon then caused a massive dissection that extended into the myocardium and immediately caused death.

The results indicate that restenosis after repeated percutaneous transluminal coronary angioplasty is caused by a fibrocellular tissue response that resembles the major event causing restenosis after the first attempt. $^{3-14}$ This is not surprising as the fibrocellular tissue reaction depends upon the presence of viable cells activated by the procedure. ${ }^{3}$ In patients who have repeated percutaneous transluminal coronary angioplasty and restenosis there is evidence of a potent growth factor and the aggregation of platelets at sites of laceration may be vital to this process. ${ }^{2021}$ In theory the more advanced the maturation of the fibrocellular response, that is when there is more collagen and fewer cells, the less likely is a second injury to cause further tissue response because the injury inflicted by the balloon affects only the acellular fibrous tissue. Because older (that is more mature) repair tissue contains fewer cells and more connective elements than

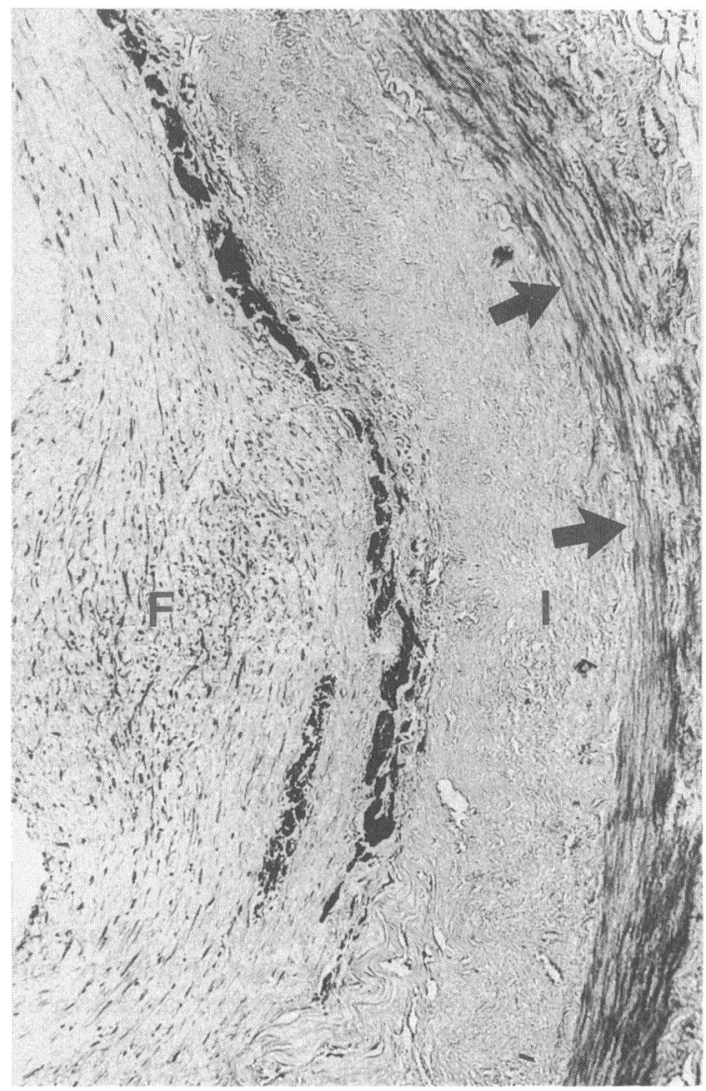

Fig 4 Photomicrograph showing detail of coronary artery with fibrocellular intimal reaction that is indicative of $a$ repair process. There are fibrin deposits within the intima separating the fibrocellular response $(F)$ from pre-existing intimal thickening (I). The media shows attenuation and separation of smooth muscle cells (arrows). This change is believed to indicate stretching of the artery by percutaneous transluminal coronary angioplasty. Phosphotungsic acid haematoxylin stain (original magnification, $\times 90$ ). 


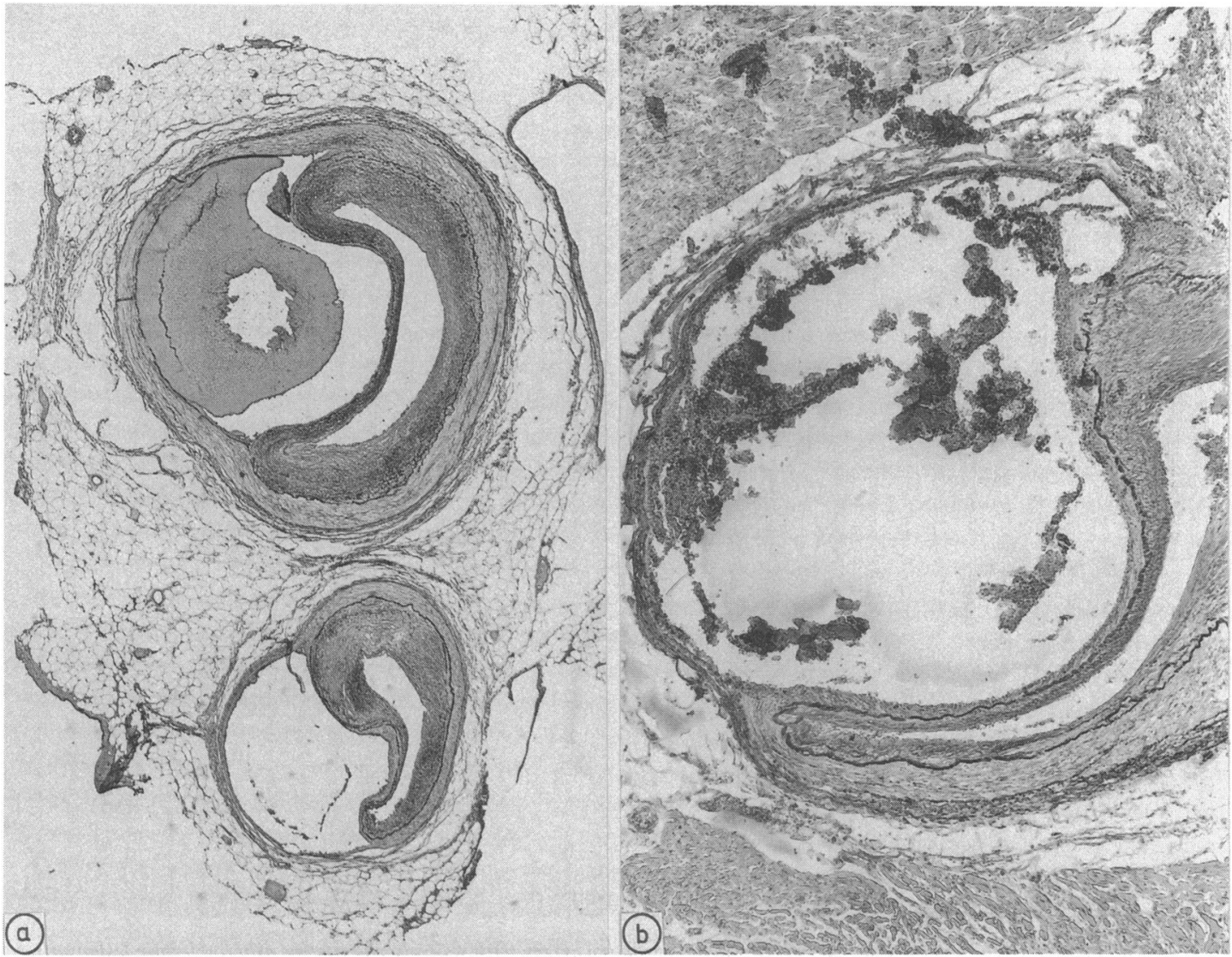

Fig 5 Photomicrograph showing medial dissection extending from the epicardial artery into intramyocardial branches. (a) Cross section through the obtuse marginal artery and a side branch, both showing medial dissection. (b) Extension of the dissection into an intramyocardial branch. Elastic tissue stains (a) original magnification, $\times 21 ;(b)$ original magnification, $\times 55$ ).

younger repair tissue (that is the loosely arranged connective tissue found soon after angioplasty), when it is disrupted by a further angioplasty procedure it is less capable of producing tissue that will obstruct the lumen. This maturation of the initial tissue response may explain why a repeat percutaneous transluminal coronary angioplasty is successful in most patients with restenosis. The composition of the atherosclerotic plaque will determine whether or not the procedure will achieve lasting success. In plaques that are mainly composed of dense fibrous tissue and almost acellular, the tissue response leading to restenosis may be minimal or even absent. On the other hand, plaque injury to cellular tissues may lead to an early response and restenosis. These theoretical considerations fit nicely with the practical approach presently advocated in patients in whom a repeat angiogram reveals restenosis. Redilatation, under such circumstances, should primarily be based on the severity of the angina pectoris, rather than on the results of the various testing procedures. ${ }^{15}$

We also found that plaque haemorrhages, which are almost certainly the result of the dilatation procedure, may become organised and incorporated into the pre-existing atherosclerotic lesion. Occasionally this may be the sole reason for early restenosis in cases where this particular mechanism probably accelerates "normal" atherosclerosis. These observations could explain why Waller et al reported that three out of four cases of late restenosis were caused by "classic" atherosclerotic lesions 

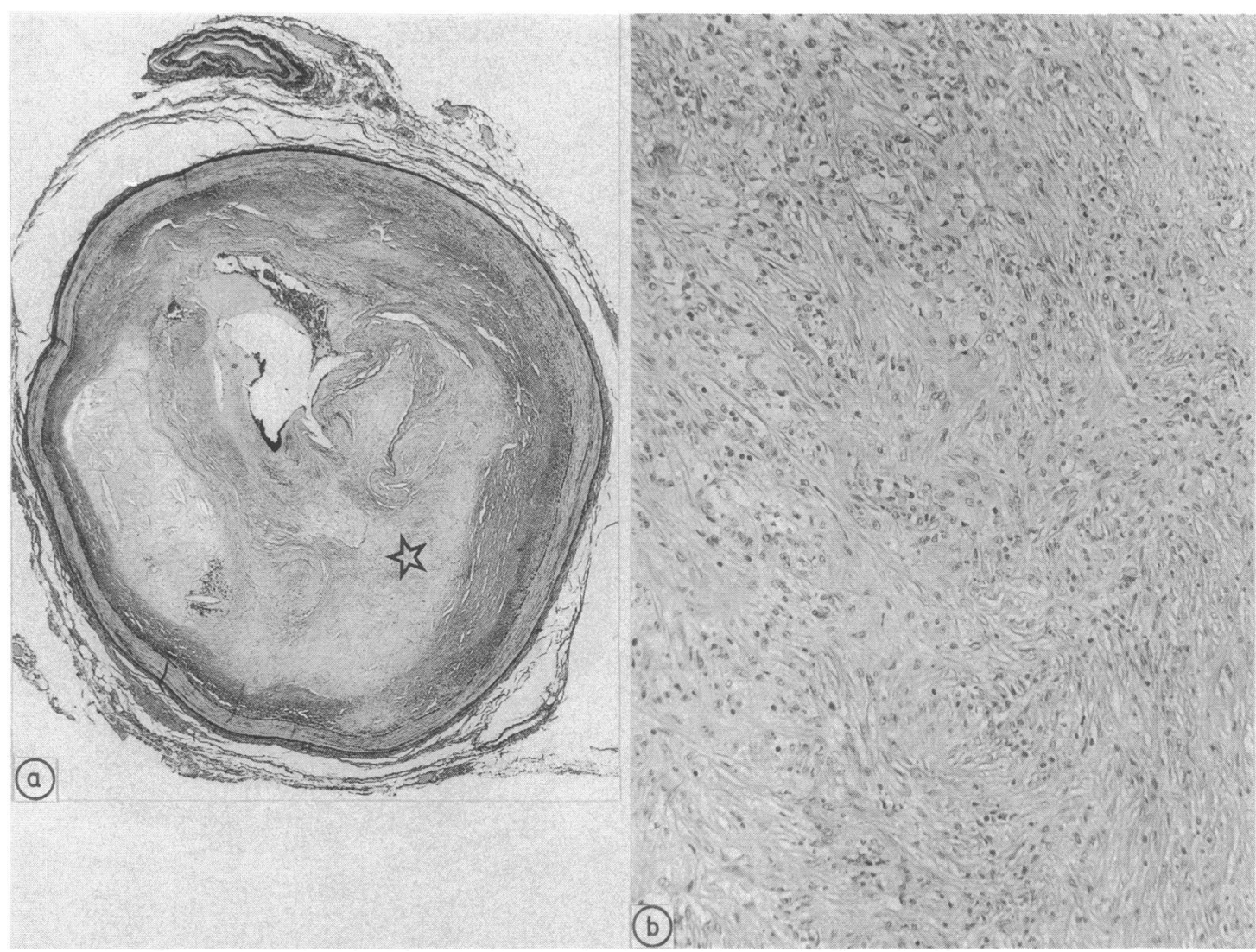

Fig 6 Photomicrograph showing cross section through a coronary artery with severely obstructive atherosclerotic lesions after percutaneous transluminal coronary angioplasty. (a) Overall view showing several sites of laceration. The area indicated by the asterisk is shown in detail in (b). It shows a organising plaque haemorrhage. (a) Elastic tissue stain (original magnification $\times 14$ ); (b) haematoxylin and eosin stain (original magnification $\times 90$ ).

without any signs attributable to a previous percutaneous transluminal coronary angioplasty. ${ }^{8}$ Similarly, Giraldo et al described a successful percutaneous transluminal coronary angioplasty of the posterior descending coronary artery, while necropsy 69 day later showed a $75 \%$ luminal obstruction by a "common atherosclerotic plaque". ${ }^{10}$

The present study indicates that fibrocellular tissue proliferation is the most common mechanism underlying restenosis, and that healing of an injured atherosclerotic plaque may occasionally be an alternative mechanism.

During the course of this study Dr Ueda was on a leave of absence from the Department of Pathology, Osaka City University Medical School, Osaka, Japan.

\section{References}

1 Holmes DR Jr, Vlietstra RE, Smith HC, et al. Restenosis after percutaneous transluminal coronary angioplasty (PTCA): a report from the PTCA Registry of the National Heart, Lung, and Blood Institute. Am J Cardiol 1984;53:77C-81C.

2 Williams DO, Gruentzig AR, Kent KM, Detre KM, Kelsey SF, To T. Efficacy of repeat percutaneous transluminal coronary angioplasty for coronary restenosis. Am J Cardiol 1984;53:32C-5C.

3 Block PC, Myler RK, Stertzer S, Fallon JT. Morphology after transluminal angioplasty in human beings. N Engl J Med 1981;52:382-5.

4 Wood WG. Transluminal coronary angioplasty [Letter]. N Engl J Med 1982;306:1055.

5 Essed CE, van den Brand M, Becker AE. Transluminal coronary angioplasty and early restenosis. Fibrocellular occlusion after wall laceration. $\mathrm{Br}$ Heart J 1983;49:393-6. 
6 Saffitz JE, Rose TE, Oaks JB, Roberts WC. Coronary arterial rupture during coronary angioplasty. $\mathrm{Am} \mathrm{J}$ Cardiol 1983;51:902-4.

7 Mizuno K, Kurita A, Imazeki N. Pathological findings after percutaneous transluminal coronary angioplasty. Br Heart $J$ 1984;52:588-90.

8 Waller BF, Gorfinkel J, Rogers FJ, Kent KM, Roberts WC. Early and late morphological changes in major epicardial coronary arteries after percutaneous transluminal coronary angioplasty. Am J Cardiol 1984;53: 42C-7C.

9 Schneider J, Grüntzig A. Percutaneous transluminal coronary angioplasty. Morphologic findings in three patients. Pathol Res Pract 1985;180:348-52.

10 Giraldo AA, Esposo OM, Meis JM, Intimal hyperplasia as a cause of restenosis after percutaneous transluminal coronary angioplasty. Arch Pathol Lab Med 1985;109:173-5.

11 Soward AL, Essed CE, Serruys PW. Coronary arterial findings after accidental death immediately after successful percutaneous transluminal coronary angioplasty. Am J Cardiol 1985;56:794-5.

12 Austin GE, Ratliff NB, Hollman J, Tabei S, Phillips DF. Intimal proliferation of smooth muscle cells as an explanation for recurrent coronary artery stenosis after percutaneous transluminal coronary angioplasty. J Am Coll Cardiol 1985;6:369-75.

13 Düber C, Jungbluth A, Rumpelt H-J, Erbel R, Meyer $\mathrm{J}$, Thoenes W. Morphology of the coronary arteries after combined thrombolysis and percutaneous transluminal coronary angioplasty for acute myocardial infarction. Am J Cardiol 1986;58:698-703.

14 Colavita PG, Ideker RE, Reimer KA, Hackel DB, Stack RS. The spectrum of pathology associated with percutaneous transluminal coronary angioplasty dur- ing acute myocardial infarction. J Am Coll Cardiol 1986;8:855-60.

15 Wijns W, Serruys PW, Reiber JHC, et al. Early detection of restenosis after successful percutaneous transluminal coronary angioplasty by exerciseredistribution thallium scintigraphy. $\mathrm{Am} J$ Cardiol 1985;55:357-61.

16 MacDonald RG, Feldman RL, Conti CR, Pepine CJ. Thromboembolic complications of coronary angioplasty. Am J Cardiol 1984;54:916-7.

17 Block PC, Elmer D, Fallon JT. Release of atherosclerotic debris after transluminal angioplasty. Circulation 1982;65:950-2.

18 Sanborn TA, Faxon DP, Waugh D, et al. Transluminal angioplasty in experimental atherosclerosis: analysis for embolization using an in vivo perfusion system. Circulation 1982;66:917-22.

19 Isner JM, Fortin RV. Frequency in nonangioplasty patients of morphologic findings reported in coronary arteries treated with transluminal angioplasty. Am J Cardiol 1982;51:689-93.

20 Faxon DP, Sanborn TA, Haudenschild CC, Ryan TJ. Effect of antiplatelet therapy on restenosis after experimental angioplasty. Am J Cardiol 1984;53: 72C-6C.

21 Steele PM, Chesebro JH, Stanson AW, et al. Balloon angioplasty. National history of the pathophysiology response to injury in a pig model. Circ Res 1985;57:105-12.

22 Austen WG, Edwards JE, Frye RL, et al. A reporting system on patients evaluated for coronary artery disease. Report of the ad hoc committee for grading of coronary artery disease, council on cardiovascular surgery, American Heart Association. Circulation 1975;51(suppl):5-40. 